\title{
Pengaruh Kompetensi Aparatur Desa, Efektivitas Pengendalian Internal Dan Moral Sensitivity Terhadap Pencegahan Fraud Dalam Pengelolaan Keuangan Desa
}

\author{
Putu Ayu Armelia ${ }^{1}$, Made Arie Wahyuni ${ }^{2}$ \\ 1,2 Program Studi S1 Akuntansi, Universitas Pendidikan Ganesha \\ Singaraja, Indonesia \\ e-mail : 1' ayuarmelia09@gmail.com, ${ }^{2}$ ariewahyuni@undiksha.ac.id
}

\begin{abstract}
Abstrak
Penelitian ini bertujuan untuk mengetahui pengaruh kompetensi aparatur desa, efektivitas pengendalian internal, dan moral sensitivity terhadap pencegahan fraud dalam pengelolaan keuangan desa di Kecamatan Banjar. Penelitian ini menggunakan pendekatan kuantitatif. Sampel penelitian berjumlah 51 orang responden yang terdiri dari kepala desa, bendahara, dan ketua Badan Permusyawaratan Desa (BPD) dari 17 desa yang ada di Kecamatan Banjar, yang ditentukan dengan metode nonprobability sampling yaitu purposive sampling. Jenis data yang digunakan adalah kuesioner yang disebar langsung kepada responden. Teknis analisis data yang digunakan adalah analisis regresi linear berganda dan penyajian data dibantu dengan program SPSS 22 for windows. Hasil penelitian ini menunjukkan bahwa kompetensi aparatur desa tidak berpengaruh terhadap pencegahan fraud dalam pengelolaan keuangan desa, efektivitas pengendalian internal berpengaruh secara positif dan signifikan terhadap pencegahan fraud dalam pengelolaan keuangan desa dan moral sensitivity berpengaruh secara positif dan signifikan terhadap pencegahan fraud dalam pengelolaan keuangan desa di Kecamatan Banjar Kabupaten Buleleng.
\end{abstract}

Kata Kunci : Kompetensi Aparatur Desa, Efektivitas Pengendalian Internal, Moral Sensitivity, Pencegahan Fraud

\begin{abstract}
This study aims to determine the effect of village apparatus competence, effectiveness of internal control, and moral sensitivity on fraud prevention in village financial management in the Banjar District. This study uses a quantitative approach. The research sample consisted of 51 respondents consisting of the village head, treasurer, and the chairman of the Village Consultative Body (BPD) from 17 villages in the Banjar District, determined by the nonprobability sampling method, namely purposive sampling. The type of data used is a questionnaire distributed directly to respondents. The data analysis technique used is multiple linear regression analysis and the presentation of data is assisted with the SPSS 22 program for windows. The results of this study indicate that the competence of village officials does not affect fraud prevention in village financial management, the effectiveness of internal control has positive and significant effect on fraud prevention in village financial management and moral sensitivity has a positive and significant effect on fraud prevention in village financial management in the District Banjar Buleleng Regency.
\end{abstract}

Keywords : village apparatus competence, effectiveness of internal control, moral sensitivity, fraud prevention

\section{Pendahuluan}

Menurut UU No. 6 Tahun 2014, desa berhak menerima dana dari APBN. Dana desa dan alokasi dana desa dalam hal pertanggungjawabannya termasuk kedalam akuntabilitas keuangan publik. Namun, akuntabilitas keuangan publik rentan terjadi penipuan saat memanajemen dana desa tersebut, jadi tidak menutup kemungkinan terjadinya kecurangan/fraud. 
Pengamatan KPK terhadap tata kelola keuangan desa memiliki beberapa masalah seperti pengawasan dan aspek kelembagaan, tata kelola, pengawasan, dan sumber daya manusia. Hal itu diakibatkan karena adanya tumpang tindih wewenang, belum terpenuhinya standar dalam laporan pertanggungjawaban desa, dan rawan manipulasi sehingga berpontensi terjadi fraud (www.citamiang.desa.id).

Amrizal (2004) menyatakan pada dasarnya, pengendalian internal yang rendah, karyawan yang tidak jujur dan tidak mempunyai kredibilitas serta model tata kelola yang sempat atau sedang melakukan penyelewengan merupakan dasar yang menyebabkan terjadinya fraud. Upaya untuk mencegah adanya penipuan dalam mengelola keuangan pedesaan maka diperlukan kompetensi dari pejabat desa yang memadai saat memanajemen keuangan desa. Dari pada itu fraud bisa juga dicegah melalui cara memperbaiki kualitas pengendalian internalnya. Menurut Udayani dan Maria (2017) integritas personal seseorang yang baik akan memberikan kontribusi untuk melaksanakan sistem pengendalian internal yang bagus pula. Semakin tinggi moralitas seseorang, semakin ia akan peduli akan relevansi yang lebih luas melebihi kepentingannya sendiri ataupun hanya kepentingan institusi saja.

Banyaknya kasus perkara atas penyelewengan dana desa yang terjadi di beberapa desa mencirikan bahwa kasus-kasus penyelewengan dalam pengelolaan keuangan desa masih relatif tinggi. Aparat desa telah mengadopsi banyak metode untuk mendapatkan kepentingannya sendiri. Seperti halnya kasus yang terjadi di Kecamatan Banjar, Kabupaten Buleleng, yaitu di Desa Dencarik. Perbekel atau Kepala Desa di Desa Dencarik pada tanggal 13 Maret 2018 terbukti melakukan korupsi dalam menganggarkan (APBDes) di tahun 2015 dan 2016 rinciannya uang dari sebagian penerimaan pendapatan desa sebesar $\mathrm{Rp}$. 105.805.000,- serta uang selisih pertanggungjawaban belanja desa setelah setoran pajak sebesar Rp. 42.125.551,- (NusaBali.com).

Selain di Desa Dencarik, kasus tindak pidana korupsi APBDes terjadi di Desa Tirtasari TA 2015, 2016, 2017. Dengan ditemukannya surat panggilan dari Satreskrim Polres Buleleng dengan nomor panggilan : B1,125/III/2019/Reskrim tertanggal 18 Maret 2019. Hasil survei data menunjukkan bahwa pada tahun fiskal 2015, berdasarkan peraturan pendapatan perangkat desa adalah sebesar 30\% yaitu Rp. 299.302.974,-- kemudian nilai subsidi pendapatan peralatan desa dimasukkan sebesar Rp. 350.000.000,- sehingga pendapatan aparat desa meningkat menjadi Rp. 410.620.964,- Pada tahun 2016 terjadi penyalahgunaan uang desa yaitu sebesar Rp. 95.644.460,- dan pada tahun 2017, anggaran APBD Desa Tirtasari juga mengalami beberapa penyimpangan. Dalam laporan pertanggungjawaban keuangan, dianggarkan pembangunan jalan sebesar Rp. 93.416.500,- tetapi jalan tersebut telah selesai dibuat pada tahun 2016. (www.BaliEditor.com). Kasus lain terjadi di Desa Banjar, pada tahun 2019 kasus penyalahgunaan dana Bantuan Keuangan Khusus (BKK) oleh kepala desa atau perbekel yang menerima bantuan khusus tersebut namun tidak melakukan kegiatan sesuai dengan proposal yang diajukan (Kumparan.com).

Faktor-faktor yang menyebabkan oknum kepala desa melakukan tindakan penyalahgunaan anggaran hingga terjadinya kecurangan dalam pengelolaan keuangan dana desa adalah kurang kompetennya aparat desa, lemahnya pengendalian internal, lemahnya sensitivitas moral para aparat desa. Kompetensi merupakan suatu keahlian, pengetahuan serta perilaku yang baik dalam diri seseorang untuk melakukan suatu pekerjaan. Menurut Sutrisno (2009) kompetensi dibutuhkan untuk menghadapi tuntutan organisasi berupa cepatnya perubahan, kompleks permasalahan, dan masa depan yang belum pasti. Dengan memanfaatkan rendahnya kompetensi aparatur desa yang lain maka oknum kepala desa melakukan tindak kecurangan, sehingga kapasitas pejabat desa yang tepat dapat mencegah terjadinya penipuan saat memanajemen keuangan pedesaan. Dengan kecakapan dan kapabilitas dari pejabat desa maka fungsi dari dana desa akan tercapai. Semakin berkompeten aparatur desa, semakin tinggi pencegahan penipuan dalam pengelolaan keuangan desa. Sehingga peneliti berasumsi bahwa :

$\mathrm{H}_{1}$ : Kompetensi aparatur desa berpengaruh positif terhadap pencegahan fraud dalam pengelolaan keuangan desa 
Selain kemampuan pejabat desa, efektivitas pengendalian internal juga mempengaruhi pencegahan penipuan dalam manajemen keuangan di tingkat pedesaan. Permatasari, dkk (2017) menyatakan bahwa sistem pengendalian internal adalah beragam kebijakan, praktik, dan prosedur yang dilaksanakan dalam perusahaan dengan tujuan melindungi aset perusahaan, mengukuhkan kecermatan dan keunggulan catatan informasi akuntansi, memajukan ketepatan guna dalam aktivitas institusi, dan menilai keteraturan peraturan serta kebijakan yang dibuat oleh manajemen. Kecurangan bisa dicegah jika pengendalian internal dilakukan secara efektif dilaksanakan di dalam suatu organisasi. Pengendalian internal sangat penting dilakukan dengan tujuan meminimalisir adanya kesempatan terjadinya kelalaian dan perilaku yang melenceng dari aturan yang ada. Jadi, niat seseorang melakukan kecurangan akuntansi disebabkan karena adanya kesempatan untuk melaksanakan tindakan tersebut. Kesempatan terjadinya kecurangan tersebut bisa dikurangi dengan menerapkan pengendalian internal yang baik, sehingga kegiatan operasional dapat berjalan dengan efektif dan efisien. Semakin efektif pengendalian internal yang diterapkan maka upaya untuk pencegahan kecurangan akan semakin baik. Sehingga peneliti berasumsi bahwa :

$\mathrm{H}_{2}$ : Efektivitas pengendalian...internal berpengaruh positif terhadap pencegahan fraud dalam pengelolaan keuangan desa

Aspek lain yang berdampak pada pencegahan fraud adalah moralitas seseorang. Moralitas adalah nilai-nilai tertentu yang dianggap baik atau buruk, dan dapat membedakan mana yang pantas atu tidak untuk dilakukan. Terjadinya tindak kecurangan akuntansi pada suatu organisasi diakibatkan oleh moralitas yang dimiliki aparat yang ada didalamnya. Setiap individu dalam suatu lembaga pasti memiliki tingkat moralitas yang beranekaragam dan akan mempengaruhi tren kecurangan akuntansi. Maka dari itu, orang yang memiliki kemampuan moral yang baik akan lebih memilih mengikuti aturan dan menghindari kecurangan untuk memperoleh keuntungan pribadi. Sehingga, peneliti berasumsi bahwa :

$\mathrm{H}_{3}$ : Moral sensitivity berpengaruh positif terhadap pencegahan fraud dalam pengelolaan keuangan desa.

Dalam manajemen keuangan penduduk desa, kemampuan aparatur desa, efektivitas pengendalian internal dan moral sensitivity memiliki hasil yang berbeda-beda. Studi oleh Wonar, dkk (2018), Laksmi dan Sujana (2019) serta Jayanti dan Suardana (2019) tentang kompetensi aparat desa menjelaskan bahwa kredibiltas yang dimiliki oleh seseorang dalam kepegawaian desa dapat berdampak positif dan signifikan pada pencegahan penipuan dalam manajemen keuangan desa. Tetapi, studi oleh Huljanah (2019) menjelaskan jika wewenang pejabat desa tidak berdampak pada pencegahan penipuan saat memanajemen keuangan desa.

Studi oleh Laksmi dan Sujana (2019), Ardiyanti dan Supriadi (2018) serta Jayanti dan Suardana (2019) mengenai sistem pengendalian internal menyatakan jika sistem kontrol internal memiliki dampak positif serta signifikn untuk mencegah kecurangan dalam pengelolaa keuangan tingkat desa. Namun, studi oleh Usman, dkk (2015) dan Huljanah (2019) menunjukkan jika sistem kontrol internal tidak memiliki dampak signifikan pada pencegahan kecurangan dalam memanajemen keuangan pedesaan.

Penelitian mengenai moral sensitivity yang dilakukan oleh Jayanti dan Suardana (2019), Rahimah, dkk (2018), Laksmi dan Sujana (2019) menyimpulkan jika etika memiliki peran positif serta penting dalam pencegahan kecurangan dalam pengelolaan keuangan pedesaan. Namun, penelitian oleh Dewi, dkk (2017) menunjukkan jika moralitas tidak memiliki dampak signifikan pada penanggulangan penipuan saat memanajemen keuangan pedesaan.

Perbedaan hasil studi dalam temuan tersebut membuat peneliti tertarik untuk melakukan penelitian berjudul "pengaruh kompetensi aparatur desa, efektivitas pengendalian internal, dan moral sensitivity terhadap pencegahan fraud dalam pengelolaan keuangan desa di Kecamatan Banjar Kabupaten Buleleng". Selain itu, adanya pertimbangan bahwa di Kecamatan Banjar belum optimal dalam menyerapkan dana desa kedalam kegiatan desa 
dan adanya desa yang tidak patuh dalam membuat Laporan Realisasi Anggaran (LRA) serta Laporan Pertanggungjawaban (LPJ) (Balipuspanews.com). Selain itu, masih terdapat kasuskasus kecurangan saat melakukan pengelolaan keuangan di pedesaan di Kecamatan Banjar Kabupaten Buleleng.

\section{Metode}

Pendekatan kuantitatif yang dilakukan dengan menyebarkan kuesioner secara langsung ke lapangan adalah metode yang digunakan dalam penelitian ini dengan populasi dalam penelitian ini adalah pemerintah desa yang memanajemen keuangan tingkat desa di 17 (tujuh belas) desa di Kecamatan Banjar, Kabupaten Buleleng yaitu pemerintah desa yang bertanggungjawab selama tahap perencanaan, tahap organisasi, tahap implementasi, tahap pelaporan, dan tahap akuntabilitas. Menurut Permendagri Nomor 113 tentang Pengelolaan Keuangan Desa tahun 2014, manajemen teknis keuangan desa adalah kepala desa, sekretaris desa, bendahara desa, dan kepala seksi. Menurut Menteri Pemberdayaan Masyarakat dan Pedesaan Kemeterian Dalam Negeri, pemantauan dana pedesaan dilaksanakan oleh BPD (Badan Permusyawaratan Desa). Penentuan sampel dalam penelitian ini diambil dengan menggunakan metode nonprobability sampling yaitu purposive sampling. Adapun sampel dalam penelitian ini sebanyak 51 orang responden yang secara riil melakukan manajemen dana desa yaitu perbekel atau kepala desa, bendahara desa serta ketua BPD (Badan Permusyaratan Desa).

Metode dalam penelitian ini adalah menggunakan analisis regresi linear berganda. Metode ini digunakan untuk menentukan dampak dari kompetensi aparatur desa, efektivitas pengendalian internal, dan moral sensitivity terhadap penanggulangan penipuan dalam memanajemen dana desa di Kecamatan Banjar melalui hasil data responden yang telah disebar oleh peneliti. Sebelum dilakukannya uji analisis regresi linear berganda pertamatama yaitu melakukan uji instrumen penelitian. Uji instrumen penelitian didalamnya terdapat uji validitas dan uji reliabilitas. Selanjutnya uji asumsi klasik yang didalamnya terdapat uji normalitas, uji multikolinearitas dan uji heteroskedastisitas. Dan setelah itu, dilakukan uji hipotesis yang didalamnya terdiri dari analisis regresi linear berganda, uji t dan koefisien determinasi dengan memanfaatkan program pada SPSS 22 for windows.

\section{Hasil Penelitian Dan Pembahasan Hasil Uji Validitas}

Uji validitas digunakan untuk mengukur valid tidaknya suatu kuesioner sebagai suatu instrumen penelitian. Pengujian dilakukan dengan tes Pearson Correlation yang ada pada program SPSS, dengan kriteria keputusan dinyatakan valid apabila nilai signifikasi dibawah 0,05 . Hasil uji validitas masing-masing pernyataan kuesioner memiliki nilai signifikasi 0,00 yaitu dibawah 0,05. Jadi dapat disimpulkan bahwa semua item pernyataan pada kuesioner adalah valid.

\section{Hasil Uji Reliabilitas}

\begin{tabular}{cccc}
\multicolumn{4}{c}{ Tabel 1. Hasil Uji Reliabilitas } \\
\hline Variabel Penelitian & Cronbach's Alpha & Standar Alpha & Keterangan \\
\hline Pencegahan Fraud $(\mathrm{Y})$ & 0,860 & 0,70 & Reliabel \\
Kompetensi & 0,805 & 0,70 & Reliabel \\
SPI & 0,707 & 0,70 & Reliabel \\
Moral & 0,756 & 0,70 & Reliabel \\
\hline
\end{tabular}

Uji reliabilitas digunakan untuk menguji apakah skor yang didapat konsisten atau stabil jika instrumen penelitian tersebut dibagikan dengan perbedaan waktu. Jika instrumen memiliki Cronbachs Alpha lebih dari 0,70, maka instrumen tersebut dianggap reliabel atau dapat diandalkan. Tabel 1 adalah hasil pengujian reliabilitas instrumen penelitian. Berdasarkan tabel 1 hasil pengujian reliabilitas masin-masing variabel yang diuji memiliki nilai Cronbachs Alpha $>0,70$. Jadi, bisa disimpulkan seluruh variabel yang ada pada penelitian ini dikatakan konsisten. 


\section{Hasil Uji Normalitas}

Uji normalitas digunakan dalam menentukan normal atau tidak distribusi variabel independen dan dependen pada model regresi. Teknik tes yang diberlakukan saat melakukan uji normalitas ini yaitu One-Sample Kolmogrov Sminorv test (1- Sampel K-S). Apabila nilai signifikasi yang didapat $>0,05$ maka data dianggap terjadi penyebaran data yang normal, namun apabila nilai signifikasi yang didapat $<0,05$ data akan dianggap tidak terjadi penyebaran data yang normal. Tabel berikut ini adalah data hasil pengujian normalitas instrumen penelitian :

Tabel 2. Hasil Uji Normalitas

\begin{tabular}{|c|c|c|}
\hline & & Unstandardized Residual \\
\hline $\mathrm{N}$ & & 51 \\
\hline \multirow[t]{2}{*}{ Normal Parameters ${ }^{a, b}$} & Mean & 0,0000000 \\
\hline & Std. Deviation & 2,73907001 \\
\hline \multirow[t]{3}{*}{ Most Extreme Difference } & Absolute & 0,103 \\
\hline & Positive & 0,103 \\
\hline & Negative & $-0,071$ \\
\hline Test Statistic & & 0,103 \\
\hline Asymp. Sig. (2-tailed) & & $0,200^{c-d}$ \\
\hline
\end{tabular}

Data uji statistik dari hasil tes menunjukkan bahwa nilai signifikansi adalah 0,200 , hal ini berarti nilai signifikasi $>0,05$. Ini menujukkan distribusi data mengalami penyebaran yang normal.

\section{Hasil Uji Multikolinearitas}

Untuk mengevaluasi apakah ada relasi antar variabel independen pada model regresi linear digunakan uji multikolinearitas. Apabila besaran VIF $<10$ dan besaran Tolerance $>$ 0,10 model regresi tidak memiliki gejala multikolinearitas. Tabel berikut ini adalah data hasil pengujian multikolinearitas instrumen penelitian:

Tabel 3. Hasil Uji Multikolinearitas

\begin{tabular}{|c|c|c|c|}
\hline Variabel Penelitian & Tolerance & VIF & Keterangan \\
\hline $\begin{array}{c}\text { Kompetensi } \\
\text { Aparatur }\end{array}$ & 0,594 & 1,684 & $\begin{array}{c}\text { Tidak terjadi } \\
\text { multikolinearitas }\end{array}$ \\
\hline $\begin{array}{c}\text { Sistem } \\
\text { Pengendalian } \\
\text { Internal }\end{array}$ & 0,615 & 1,626 & $\begin{array}{c}\text { Tidak terjadi } \\
\text { multikolinearitas }\end{array}$ \\
\hline Moral Sensitivity & 0,928 & 1,926 & $\begin{array}{c}\text { Tidak terjadi } \\
\text { multikolinearitas }\end{array}$ \\
\hline
\end{tabular}

Berdasarkan tabel 3 nilai Tolerance masing-masing variabel lebih dari 0,10, sedangkan nilai Varian Inflation Factors (VIF) tidak lebih dari 10. Dari hasil uji multikolinearitas tersebut dapat dikatakan bahwa dalam penelitian ini model regresi tidak mengalami masalah multikolinearitas.

\section{Uji Heteroskedastisitas}

Dalam menguji variabilitas residual pada satu penelitian ke penelitian yang lainnya dalam model regresi digunakan uji asumsi klasik heteroskedastisitas. Untuk mendeteksi masalah heterokedastisitas dilakukan dengan menggunakan regresi nilai absolut residual (ABS_RES) kepada variabel bebas dalam uji statistik glejser. Apabila tidak terjadi masalah heteroskedastisitas maka jumlah signifikansi $t$ harus $>0,05$. Sedangkan apabila terjadi masalah heteroskedastisitas maka jumlah signifikansi t bisa $<0,05$. Tabel berikut adalah hasil pengujian heteroskedastisitas instrumen penelitian 
Tabel 4. Hasil Uji Heteroskedastisitas

\begin{tabular}{cccc}
\hline Variabel & Thitung $_{\text {Kompetensi }}$ & Sig. & Keterangan \\
\hline $\begin{array}{c}\text { Aparatur } \\
\text { SPI }\end{array}$ & $-1,016$ & 0,315 & $\begin{array}{c}\text { Tidak terjadi masalah } \\
\text { heteroskedastisitas } \\
\text { Tidak terjadi masalah } \\
\text { heteroskedastisitas }\end{array}$ \\
Moral Sensitivity & 1,798 & 0,079 & $\begin{array}{c}\text { Tidak terjadi masalah } \\
\text { heteroskedastisitas }\end{array}$ \\
\hline
\end{tabular}

Menurut hasil tes, nilai signifikansi setiap variabel lebih besar dari pada 0,05 . Jadi dari masing-masing variabel dalam penelitian ini tidak terjadi heteroskedastisitas.

\section{Hasil Uji Analisis Regresi Linear Berganda}

Dalam penelitian untuk dapat mengevaluasi akibat lebih dari dua atau lebih variabel independen dengan variabel dependen menggunakan teknik uji hipotesis analisis regresi linear berganda. Berikut ini adalah hasil pengujian analisis regresi linear berganda dari instrumen penelitian

Tabel 5. Hasil Analisis Regresi Linear Berganda

\begin{tabular}{|c|c|c|c|c|c|}
\hline \multirow[b]{2}{*}{ Model } & \multicolumn{2}{|c|}{$\begin{array}{l}\text { Unstandardized } \\
\text { Coefficients }\end{array}$} & \multirow{2}{*}{$\begin{array}{c}\text { Standardized } \\
\text { Coefficients } \\
\text { Beta }\end{array}$} & \multirow{3}{*}{$\frac{t}{2,268}$} & \multirow{3}{*}{$\frac{\text { Sig. }}{0,028}$} \\
\hline & $\mathrm{B}$ & Std. Error & & & \\
\hline $\begin{array}{ll}1 & \text { (Constant) }\end{array}$ & 15,472 & 6,823 & & & \\
\hline $\begin{array}{l}\text { KompetensI } \\
\text { Aparatur }\end{array}$ & 0,328 & 0,203 & 0,262 & 1,613 & 0,113 \\
\hline $\begin{array}{l}\text { SPI } \\
\text { Moral Sensitivity }\end{array}$ & $\begin{array}{l}0,404 \\
0,668\end{array}$ & $\begin{array}{l}0,192 \\
0,173\end{array}$ & $\begin{array}{l}0,336 \\
0,501\end{array}$ & $\begin{array}{l}2,104 \\
3,854\end{array}$ & $\begin{array}{l}0,041 \\
0,000\end{array}$ \\
\hline
\end{tabular}

Dari tabel 5 hasil analisis regresi linear berganda maka terjadi persamaan regresi seperti berikut :

$$
\begin{aligned}
& Y=\alpha+\beta_{1} X_{1}+\beta_{2} X_{2}+\beta_{3} X_{3}+e \\
& Y=15,472+0,328+0,404+0,668+e
\end{aligned}
$$

Dari terbentuknya persamaan regresi tersebut, dapat diuraikan seperti berikut ini :

Konstanta $(\alpha)=15,472$, menggambarkan bahwa jika variabel kompetensi aparatur, efektivitas pengendalian internal dan moral sensitivity bernilai konstan sehingga rata-rata variabel pencegahan fraud meningkat sebesar 15,472.

Koefisien regresi linear dari variabel kompetensi aparatur yaitu 0,328 yang menunjukkan jika kompetensi aparatur meningkat satu unit jika dimisalkan variabel lain tidak berubah, pencegahan kecurangan akan meningkat sejumlah 0,328 . Koefisien positif menunjukkan bahwa ada hubungan positif antara kompetensi aparatur dengan pencegahan kecurangan.

Koefisien regresi linear dari variabel efektivitas pengendalian internal yaitu 0,404 . Koefisien positif menunjukkan bahwa ada hubungan positif antara efektivitas pengendalian internal terhadap pencegahan terjadinya kecurangan. Hal tersebut menunjukkan jika efektivitas pengendalian internal meningkat satu unit apabila dimisalkan bahwa variabel lain berkesinambungan, pencegahan kecurangan akan meningkat sejumlah 0,404.

Koefisien regresi linear dari variabel moral sensitivity adalah 0,668 bernilai positif. Hal tersebut menunjukkan jika moral sensitivity meningkat satu unit jika dimisalkan bahwa variabel lain tidak berubah-ubah, pencegahan kecurangan akan meningkat sejumlah 0,668.

\section{Hasil Uji Parsial (Uji t)}

Dalam menguji variabel independen (kompetensi aparatur desa, pengendalian internal, dan moral sensitivity) secara parsial atau individu mempengaruhi variabel dependen (pencegahan fraud) yaitu digunakan pengujian hipotesis uji t. Saat pengujian, dilakukan 
perbandingan antara thitung dengan $t_{\text {tabel }}$ menggunakan taraf signifikan $(\alpha)=5 \%$. Jika nilai signifikasi yang didapatkan menunjukkan $\mathrm{P}<0.05$ maka dapat diartikan jika variabel independen berpengaruh signifikan dengan variabel dependen.

Berdasarkan tabel 5 maka dapat disimpulkan Hasil uji t signifikasi variabel kompetensi aparatur sebesar 0,113 $>0,05$ atau thitung $=1.613<t_{\text {tabel }}=2,012$. Jadi, kesimpulan yang didapat yaitu tidak adanya pengaruh yang signifikan antara variabel kompetensi aparatur terhadap pencegahan fraud.

Signifikansi dari hasil uji t untuk variabel efektivitas pengendalian internal adalah 0,041 $<0,05$ atau $t_{\text {hitung }}=2,104<\mathrm{t}_{\text {tabel }}=2,012$. Jadi, kesimpulannya adalah adanya dampak positif serta signifikan antara variabel efektivitas pengendalian internal dengan pencegahan fraud.

Signifikansi dari hasil uji t untuk variabel moral sensitivity adalah 0,000 $<0,05$ atau $t_{\text {hitung }}=3,854>t_{\text {tabel }}=2,012$. Jadi, kesimpulan yang dapat diambil dalam uji tersebut yaitu adanya dampak positif dan juga signifikan antara variabel moral sensitivity dengan pencegahan fraud.

\section{Uji Koefisien Determinasi $\left(\mathbf{R}^{2}\right)$}

Uji $R^{2}$ digunakan untuk mengetahui presentase pengaruh variabel bebas (variabel independen) yang dimasukkan ke dalam model yang mempengaruhi variabel terikat (variabel dependen), dan variabel lain yang tidak ada dalam penelitian ini mempengaruhi persentasenya yang lain. Tingkat akurasi regresi diwakili oleh koefisien $\left(R^{2}\right)$ antara nilai-nilai $0-1$. Jika $R^{2}$ menunjukkan bahwa variabel independen mempengaruhi variabel dependen bersama-sama. Berikut ini adalah hasil pengukuran instrumen penelitian :

Tabel 6. Hasil Uji Koefisien Determinasi

\begin{tabular}{ccccc}
\hline Model & $\mathrm{R}$ & $R$ Square & $\begin{array}{c}\text { Adjusted } R \\
\text { Square }\end{array}$ & $\begin{array}{c}\text { Sts. Error of } \\
\text { the Estimate }\end{array}$ \\
\hline 1 & $0,513^{\mathrm{a}}$ & 0,263 & 0,216 & 2,697 \\
\hline
\end{tabular}

Dari tabel 4.13 diatas diketahui jika Adjusted $R$ Square dalam penelitian ini senilai 0,216 yang menunjukkan bahwa pencegahan fraud dipengaruhi oleh kompetensi aparatur, efektivitas pengendalian internal dan moral sensitivity. Hal ini berarti pencegahan fraud dipengaruhi oleh 3 variabel bebas tersebut hanya senilai $21,6 \%$ dan $78,4 \%$ sisanya dipengaruhi oleh variabel lain yang tidak dimasukkan dalam penelitian ini.

\section{Pengaruh Kompetensi Aparatur Desa terhadap Pencegahan Fraud dalam Pengelolaan Keuangan Desa}

Hasil uji t signifikasi hipotesis pertama $\left(\mathrm{H}_{1}\right)$ variabel kompetensi aparatur senilai 0,113 $>0,05$ atau $t_{\text {hitung }}=1.613<t_{\text {tabel }}=2,012$, sehingga hipotesis yang diajukan ditolak. Oleh karena itu dapat disimpulkan bahwa variabel kompetensi aparatur desa tidak secara signifikan mempengaruhi pencegahan fraud, sehingga hipotesis $1\left(\mathrm{H}_{1}\right)$ ditolak. Fungsi aparatur tidak mempengaruhi pencegahan fraud pada manajemen keuangan pedesaan di Kecamatan Banjar karena sebagian besar aparat desa memiliki konteks pendidikan yang tidak sama dengan posisi yang dipegang. Terkendalanya aparat desa dalam proses pengelolaan dana desa disebabkan karena pengalaman kerja aparat desa masih baru serta masa kerja yang masih relatif sedikit. Dalam hal latar belakang pendidikan aparat desa di Kecamatan Banjar, tingkat SMA/SLTA terdapat 26 orang atau setara dengan 51,0\%, tingkat diploma sebanyak 5 orang atau setara dengan $9,8 \%$, serta di tingkat sarjana sebanyak 20 orang atau setara dengan $39,2 \%$. Hal ini berkaitan dengan latar belakang dan jenjang pendidikan yang sinkron keahlian seseorang merupakan indikator pengukuran kompetensi aparatur.

Hasil uji pada penelitian ini sependapat dengan penelitian Huljanah (2019) yang menjelaskan jika kompetensi aparatur tidak memiliki dampak terhadap pencegahan tindak penipuan dalam memanajemen keuangan pedesaan pada pemerintahan desa di Kecamatan Baki yang diakibatkan oleh banyaknya pejabat desa dengan konteks pendidikan yang tidak sama dengan posisi yang dipegang. Berdasarkan penelitian terdahulu, penelitian ini 
didukung oleh keyakinan bahwa kompetensi aparatur desa tidak berdampak terhadap pencegahan terjadinya penipuan dalam memanajemen keuangan pedesaan. Tetapi studi oleh Wonar, dkk (2018), Laksmi dan Sujana (2019) serta Jayanti dan Suardana (2019) bertentangan dengan penelitian ini, yang menyatakan bahwa adanya pengaruh antara kompetensi aparatur desa dengan pencegahan tindak penipuan saat melakukan tugas memanajemen keuangan yang ada di desa.

\section{Pengaruh Efektivitas Pengendalian Internal terhadap. Pencegahan Fraud dalam. Pengelolaan Keuangan Desa}

Hasil uji t signifikasi hipotesis kedua $\left(\mathrm{H}_{2}\right)$ variabel efektivitas pengendalian internal senilai $0,041<0,05$ atau thitung $=(2,104)>t_{\text {tabel }}=2,012$. Oleh karena itu kesimpulannya adalah variabel efektivitas pengendalian internal mempengaruhi pencegahan fraud secara positif dan signifikan, sehingga hipotesis $2\left(\mathrm{H}_{2}\right)$ diterima. Jadi, di dapat kesimpulan adanya dampak positif serta signifikan antara variabel efektivitas pengendalian internal dengan pencegahan fraud, sehingga hipotesis $2\left(\mathrm{H}_{2}\right)$ diterima. Dengan memadainya sistem pengendalian internal dalam suatu instansi, menyebabkan penyusunan laporan keuangan ataupun laporan pertanggungjawaban dapat meminimalisir risiko terjadinya kesalahan, sehingga laporan keuangan atau laporan pertanggungjawaban yang dibuat berkualitas sesuai dengan peraturaan yang ada dan dapat dipertanggungjawabkan. Dari penelitian yang dilakukan oleh peneliti dengan langsung ke lapangan, menunjukkan sistem kontrol internal aparat desa di Kecamatan Banjar adalah kuat dan dapat meminimalisir terjadinya kecurangan. Sistem kontrol internal yang baik tersebut didukung oleh lingkungan kontrol (tindakan, kebijakan dan prosedur manajemen), penilaian risiko/analisis risiko, strategi pengontrolan, informasi dan komunikasi, dan evaluasi yang dilakukan oleh BPD (Badan Permusyawaratan Desa). Pemerintah desa telah memahami mengenai pentingnya pengendalian internal yang merupakan tanggungjawab semua pihak. Dengan menerapkan dan memelihara kontrol internal, maka dapat meminimalisir kecurangan dalam mengelola dana desa sehingga menciptakan aktivitas yang sesuai dengan tujuan dan dengan cara yang benar serta cepat dan dapat menghemat waktu, pelaporan keuangan yang reliabel serta taat kepada peraturan dan hukum yang ada dalam memanajemen dana pedesaan.

Penelitian ini konsisten dengan studi oleh Laksmi dan Sujana (2019), Ardiyanti dan Supriadi (2018) serta Jayanti dan Suardana (2019) yang menunjukkan bahwa terdapat pengaruh yang positif antara sistem kontrol internal pada pencegahan penipuan dalam pengelolaan dana pedesaan. Dengan adanya sistem kontrol yang kuat bisa meminimkan risiko kekeliruan saat penyusunan laporan keuangan. Berdasarkan penelitian terdahulu, adanya dukungan bahwa sistem kontrol internal dapat mempengaruhi secara positif pada pencegahan penipuan dalam memanajemen keuangan pedesaan. Tetapi, simpulan penelitian ini kontras dengan studi oleh Usman, dkk (2015) serta Huljanah (2019) yang menunjukkan bahwa tidak ada dampak yang signifikan antara sistem kontrol internal dan pencegahan penipuan dalam pengelolaan keuangan pedesaan.

\section{Pengaruh Moral Sensitivity terhadap Pencegahan Fraud dalam Pengelolaan Keuangan Desa}

Hasil uji t signifikasi hipotesis ketiga $\left(\mathrm{H}_{3}\right)$ variabel moral sensitivity senilai $0,000<0,05$ dan $t_{\text {hitung }}=3,854>t_{\text {tabel }}=2,012$. Berdasarkan uji tersebut, maka disimpulkan jika adanya pengaruh secara positif dan juga signifikan antara variabel moral sensitivity denganpencegahan fraud, sehingga hipotesis $3\left(\mathrm{H}_{3}\right)$ diterima. Seperti konsep yang dikemukakan oleh Kohlberg (1971) yang menyatakan bahwa perkembangan moral terjadi pada 3 tahap yaitu tahap 1 (pre-conventional), tahap 2 (conventional) dan tahap paling tinggi yaitu tahap 3 (post-conventional), maka pemerintah desa harus menjalankan kewajibannya dan bertanggungjawab penuh kepada masyarakat yang ada di desa yang bersangkutan, pemerintah daerah, serta pemerintah pusat dalam mengelola keuangan pedesaan yang sesui dengan peraturan dan Undang-Undang yang berlaku. Penganggaran dana desa harus sinkron dengan apa yang dibutuhkan desa serta masyarakat dalam upaya untuk pembangunan pedesaan dan pemberdayaan masyarakat yang ada di desa yang 
bersangkutan. Agar pengelolaan dana desa sinkron dengan keperluan desa dan masyarakatnya, maka sangat dibutuhkan pemerintah desa yang memiliki moralitas yang baik. Berdasarkan penelitian yang dilakukan langsung ke lapangan, aparat desa diberikan pembinaan dalam hal kejujuran dan tanggungjawabnya sebagai pejabat desa dalam melaksanakan tugas untuk mengelola keuangan desa.

Hasil penelitian ini konsisten dengan penelitian yang dilakukan oleh Jayanti dan Suardana (2019), Rahimah, dkk (2018) serta Laksmi dan Sujana (2019) yang mengungkapkan bahwa moralitas memiliki efek positif pada penanggulangan penipuan dalam memanajemen dana yang ada di pedesaan. Menurut penelitian sebelumnya, adanya bukti bahwa moralitas dapat berdampak positif pada pencegahan penipuan dalam memanajemen keuangan pedesaan. Namun, hasil penelitian ini tidak sama dengan penelitian Dewi, dkk (2017) temuannya menunjukkan bahwa moralitas tidak memiliki dampak signifikan pada pencegahan penipuan.

\section{Simpulan Dan Saran}

Berdasarkan hasil analisis data dan pembahasan hipotesis, dapat ditarik simpulan bahwa kompetensi aparatur desa tidak mempengaruhi pencegahan fraud dalam pengelolaan keuangan di tingkat desa di Kecamatan Banjar, sementara sistem pengendalian internal dan Moral sensitivity akan mempengaruhi secara positif dan signifikan pencegahan fraud saat pengelolaan keuangan pada tingkat desa di Kecamatan Banjar.

Dalam penelitian ini, peneliti dapat memberikan saran yaitu bagi pemerintah desa perlu untuk mengikuti sosialisasi serta bimbingan teknis dalam pengelolaan keuangan desa dan meningkatkan kinerjanya agar aparatur desa bisa terus meningkatkan pemahaman tentang manajemen keuangan desa dan mencegah terjadinya penipuan. Aparat pedesaan disarankan pula untuk terus meningkatkan pengendalian internal serta moralitas yang dimilikinya agar penipuan dalam memanajemen keuangan desa bisa semakin diminimalisir.

Berdasarkan hasil perhitungan koefisien determinasi yaitu sebesar $21,6 \%$ dan $78,4 \%$ sisanya dipengaruhi oleh variabel yang tidak dimasukkan dalam penelitian ini. Maka peneliti menyarankan kepada peneliti selanjutnya untuk dapat memperluas area penelitian serta disarankan untuk menggunakan variabel tertentu yang bisa berpengaruh pada pencegahan fraud dalam manajemen keuangan pedesaan misalnya budaya organisasi, whistleblowing system serta ketaatan pelaporan keuangan.

\section{Daftar Pustaka}

Amrizal. 2004. Pencegahan dan Pendeteksian kecurangan oleh internal auditor. Jakarta: Direktorat Investigasi BUMN dan BUMD Deputi Bidang Investigasi.

Anonim. 2018. "KPK Temukan 14 Potensi Persoalan Pengelolaan Dana Desa”. Tersedia pada https://www.citamiang.desa.id/berita/detail/kpk-temukan-14-potensi-persoalanpengelolaan-dana-desa. (diakses pada tanggal 7 Februari 2020)

Ardiyanti, Anita dan Yudi Nur Supriad. 2018. "Efektivitas Pengendalian Internal, dan Kompetensi Sumber Daya Manusia Terhadap Implementasi Good Governance serta Implikasinya pada Pencegahan Fraud dalam Pengelolaan Keuangan Desa di Kabupaten Tangerang". Universitas Muhammadiyah Tangerang : Jurnal Manajemen Bisnis Volume 8 Nomor 1 ISSN : 2302-3449.

Bali Editor. 2019. "Diduga Terjadi Penyalahgunaan Dana APBDesa Hampir Rp $1 \mathrm{M}$ di Desa Tirtasari". Tersedia pada https://balieditor.com/diduga-terjadi-penyalahgunaan-danaapboles-hampir-rp-1-m-di-desa-tirtasari/. (diakses pada tanggal 6 Februari 2020).

Bali Puspa News. 2019. "29 Desa di Buleleng Terancam Tak Dapat Cairkan Dana Desa". Tersedia pada https://www.balipuspanews.com/29-desa-di-buleleng-tak-dapat-cairkandana-desa.html . (diakses pada tanggal 2 April 2020) 
Dewi, Putu Feny Kharisma, dkk. 2017. "Pengaruh Moralitas, Integritas, Komitmen Organisasi, dan Pengendalian Internal Kas Terhadap Pencegahan Kecurangan (Fraud) dalam Pelaksanaan Program Subsidi Beras Bagi Masyarakat Berpendapatan Rendah (Studi Pada Desa di Kabupaten Buleleng)". E-Journal S1 Akuntansi Universitas Pendidikan Ganesha, 8(2).

Huljanah, Dwi Nur. 2019. Pengaruh Kompetensi Aparatur, Sistem Pengendalian Internal, dan Moralitas Individu terhadap Pencegahan Fraud Pengelolaan Keuangan Desa. Tugas Akhir. Surakarta : Institut Agama Islam Negeri Surakarta.

Jayanti, Luh Sri Isa Dewi dan Ketut Alit Suardana. 2019. "Pengaruh Kompetensi SDM, Moralitas, Whistleblowing dan SPI terhadap Pencegahan Fraud dalam Pengelolaan Keuangan Desa". Universitas Udayana : e-Jurnal Akuntansi Vol.29 No.3 e-ISSN 23028556.

Kohlberg, Lawrence. 1971. From Is to Ought: How to Commit the Naturalistic Fallacy and Get Away with It in the Study of Moral Development. Academic Press.

Kumparan. 2019. "3 Kasus Korupsi di Buleleng dan Denpasar Disidik Kejati Bali”. Tersedia pada https://kumparan.com/kanalbali/3-kasus-korupsi-di-buleleng-dan-denpasardisidik-kejati-bali-1sPbem8q342. (diakses pada tanggal 6 Februari 2020).

Laksmi, Putu Santi Putri dan I Ketut Sujana. 2019. "Pengaruh Kompetensi SDM, Moralitas dan Sistem Pengendalian Internal terhadap Pencegahan Fraud dalam Pengelolaan Keuangan Desa". Universitas Udayana : E-jurnal Akuntansi Volume 26.3 Maret (2019) :2155-2181.

Nusa Bali. 2018. "Divonis 1 Tahun, Perbekel Dencarik Langsung Terima”. Tersedia pada https://www.nusabali.com/berita/27225/divonis-1-tahun-perbekel-dencarik-langsungterima. (diakses pada tanggal 6 Februari 2020).

Permatasari, Dini. Taufik Kurrohman, dan Kartika. 2017. "Analisis Faktor-Faktor yang Mempengaruhi Terjadinya Kecurangan (Fraud) di Sektor Pemerintah (Studi pada Pegawai Keuangan Pemerintah Kabupaten Banyuwangi)". Jurnal Keuangan dan Perbankan, Vol. 14. No. 1, 37-44

Rahimah, Laila, dkk. 2018. "Pengaruh Penyajian Laporan Keuangan, Lingkungan Pengendalian, dan Moralitas Individu terhadap Pencegahan Fraud Dalam Pengelolaan Alokasi Dana Desa”. Jurnal IImiah Ilmu Ekonomi, Vol. 6. No. 12, 139-154.

Sutrisno, Edy. 2009. Budaya Organisasi. Jakarta: Kencana

Udayani, A. A. K. F. dan Maria M. 2017. "Pengaruh Pengendalian Internal dan Moralitas Individu pada Kecenderungan Kecurangan Akuntansi”. Jurnal Akuntansi Universitas Udayana, Vol. 18, No.3, 1774-1799.

Usman, B. A. U. T. T. dan M. R. 2015. "Pengaruh Tata Kelola Pemerintahan Dan Pengendalian Internal Terhadap Pencegahan Kecurangan (Studi Pada SKPD Pemerintah Kabupaten Indragiri Hilir)". Jurnal Ekonomi, 23, 18-34.

Wonar, Klara, dkk. 2018. "Pengaruh Kompetensi Aparatur, Ketaatan Pelaporan Keuangan dan Sistem Pengendalian Intern terhadap Pencegahan Fraud dengan Moral Sensitivity sebagai Variabel Moderasi". Universitas Cendrawasih : Jurnal Akuntansi, Audit \& Aset Volume 1 Nomor 2. 